\title{
Evaluation of Izmir Tulum cheese pieces by drying with tray dryer at different air flow rates and temperatures
}

\author{
Kizilalp, G.; Polat, I.; Urgu, M.; Koca, N.* \\ Ege University, Engineering Faculty, Food Engineering Department, Izmir, Turkey \\ *E-mail of the corresponding author: nurcan.koca@ege.edu.tr
}

\begin{abstract}
Izmir tulum cheese pieces were dried using a tray dryer at different air flow rates $(1.0$ and $1.8 \mathrm{~m} / \mathrm{s})$ and temperatures $\left(45^{\circ} \mathrm{C}, 55^{\circ} \mathrm{C}\right.$ and $\left.65^{\circ} \mathrm{C}\right)$. The increase in temperature and air flow rate increased bulk and tapped bulk densityand decreased the water holding capacity. The lowest lightness and highest redness were obtained in samples dried at $65^{\circ} \mathrm{C}$. The samples dried at $55^{\circ} \mathrm{C}$ and $1 \mathrm{~m} / \mathrm{s}$ had the highest flavor and overall impression scores. As a result, a dried cheese product to benefit from left-over pieces obtained during packaging was developed, having advantages such as easy to transport, store and package.
\end{abstract}

Keywords: Izmir Tulum cheese; tray dryer; physical, chemical and sensory properties. 


\section{Introduction}

Drying is one of the oldest method and has recently been applied to various food products to gain different functions. Cheese is exposed to drying process to increase its shelf life, decrease the transport and storage costs and improve some functional properties. Dehydrated cheese is generally used as a food ingredient to improve the flavor and mouthfeel of cheese $[1,2,3]$.

Izmir Tulum cheese is a Turkish traditional cheese produced mostly by small or medium scale dairies. It is one of most consumed cheese type in Turkey, characterized with a white or cream color, high fat content, a crumbly and semi-hard texture. During the production of Izmir Tulum cheese, cheese pieces are left-over in large quantities during packaging of the cheese in the industrial production. The goal of the research is to evaluate these cheese pieces by drying with tray dryer which is the easiest drying method of producing dehydrated cheese in small scale dairies. The final quality of the dried cheese can be significantly affected by drying conditions. Therefore, it is necessary to evaluate the drying conditions to obtain a dehydrated food with a high quality. With this research, a new dehydrated cheese product was developed as an ingredient for different purposes in foods such as using in pasta, salad and pizza, etc. and the new product gives an advantages to consumer to use easily at home.

\section{Materials and Methods}

\subsection{Material}

Izmir tulum cheese purchased from the local market in Izmir. Samples were transported under cold conditions to the laboratory. Cheeses were grinded to obtain homogenous sample and dry easily. Samples were processed within a day.

\subsection{Drying process}

The preliminary tests were carried out to determine the duration of drying. The water activity value was considered to be below 0.8 . For drying of cheese, 100 grams of grated cheese samples were put on a tray and dried in a pilot-scale tray drier (TK Lab5, Turkey) at different air flow rates $(1 \mathrm{~m} / \mathrm{s}$ and $1.8 \mathrm{~m} / \mathrm{s})$ and temperatures $\left(45^{\circ} \mathrm{C}, 55^{\circ} \mathrm{C}, 65^{\circ} \mathrm{C}\right)$ for two hours. Dried cheese samples were grinded by food processor (Tefal Masterbland). Grinded dried cheese pieces were kept in glass jars during the analyses. Production procedure was replicated twice. 


\subsection{Compositional analysis}

Moisture and ash contents of cheese and dried cheese samples were determined by gravimetric method [4, 5]. Kjeldahl method was used for protein content of the samples [5]. Fat contents of cheese and dried cheese samples were determined by Van Gulik [6] and Gerber [7] methods, respectively. $\mathrm{pH}$ values of cheese and dried cheese samples were measured with a digital $\mathrm{pH}$ meter ( $\mathrm{pH}$ 320, WTW, 82362 Weilheim, Germany), and titratable acidity was expressed as percent lactic acid [5].

\subsection{Water activity}

Water activity of dried cheese samples were measured by using a water activity measurement device (Testo, Freiburg, Germany).

\subsection{Bulk, tapped densities and Carr Index value}

Bulk density of the dried samples was measured by pouring the samples to the $100-\mathrm{ml}$ measuring cylinder and recorded the weight [8]. The measuring cylinder was tapped 200 times and the volume was recorded to calculated the tapped density [8]. Carr Index values of dried cheese samples were also evaluated according to Equation 1 [9].

$$
C l=\frac{\left(\rho_{\text {tapped }}-\rho_{\text {bwik }}\right)}{\rho_{\text {tapped }}} \times 100
$$

\subsection{Water holding capacity}

Water holding capacity (WHC) of dried cheese samples were measured according to Heywood et al. [10] and Traynham et al. [11] with some modifications. $2.5 \mathrm{~g}$ of dried samples was weighed to $50 \mathrm{ml}$ centrifuge tube. Then, for each sample $10 \mathrm{~mL}$ of distilled water were added and well mixed with the sample. Samples stood at room temperature for 3 hours. The mixture was centrifuged at $2680 \mathrm{rpm}$ for $30 \mathrm{~min}$. Just after centrifugation, the supernatant was carefully decanted and the new mass of the sample was recorded. WHC (\%) was calculated as Equation 2 :

$$
\text { WHC }(96)=\frac{\text { Total water mass }}{\text { D } y \text { matter masa }}
$$

\subsection{Color evaluation}

Color values of cheese and dried cheese samples were measured in terms of L (lightness), a (redness and greenness), and $\mathrm{b}$ (yellowness and blueness) using a Hunter ColorFlex colorimeter (HunterLabColorFlex CFLX 45-2 colorimeter). Then, color differences $(\Delta \mathrm{E})$ and chroma values (color intesity) of the samples were calculated using Equations 3 and 4, 
respectively [12]. Color values of Izmir tulum cheese was taken as reference for the calculation of color differences.

$$
\begin{aligned}
& \Delta E=\sqrt{\left(\bar{L}_{0}-E\right)^{2}+\left(a_{0}-a\right)^{2}+\left(b_{0}-b\right)^{2}} \\
& \text { Wroma }=\sqrt{a^{2}+b^{2}}
\end{aligned}
$$

\subsection{Sensory evaluation}

Desirability of dried cheese samples scales in terms of color, appearance, texture, taste and overall acceptability using unipolar scales were determined by 40 panelists. . Unipolar scale ratings between 1 and 5 referring from not like at all to like very much.

\subsection{Statistical analysis}

Statistical data analyses was performed by using SPSS version 21.0. Data was analyzed by analysis of variance (ANOVA) and Duncan's multiple range test at 95\% confidence interval.

\section{Results and Discussion}

\subsection{Chemical composition}

The moisture, ash, protein fat, titratable acidity values varied from 13.02 to $16.74 \%$, from 8.79 to $9.53 \%$, from 36.55 to $40.10 \%$, from 36.28 to $37.71 \%$ and from 1.494 to $1.674 \%$, respectively (Table 1). Different drying conditions did not have any significant effect on moisture and water activity values of samples. The higher fat values were obtained in samples dried at $45^{\circ} \mathrm{C}$ for both flow rates. Increasing temperature at the same air flow rate resulted in a decrease in acidity values.

\begin{tabular}{|c|c|c|c|c|c|c|c|}
\hline Analysis & Cheese & $1 \mathrm{~m} / \mathrm{s}-45^{\circ} \mathrm{C}$ & $1 \mathrm{~m} / \mathrm{s}-55^{\circ} \mathrm{C}$ & $1 \mathrm{~m} / \mathrm{s}-65^{\circ} \mathrm{C}$ & $1,8 \mathrm{~m} / \mathrm{s}-45^{\circ} \mathrm{C}$ & $1,8 \mathrm{~m} / \mathrm{s}-55^{\circ} \mathrm{C}$ & $1,8 \mathrm{~m} / \mathrm{s}-65^{\circ} \mathrm{C}$ \\
\hline Moisture (\%) & $44,19 \pm 0,08$ & $16,74 \pm 2,11^{\mathrm{a}}$ & $16,60 \pm 1,31^{\mathrm{a}}$ & $13,02 \pm 0,27^{\mathrm{a}}$ & $14,24 \pm 1,72^{\mathrm{a}}$ & $15,52 \pm 1,52^{\mathrm{a}}$ & $14,28 \pm 2,20^{\mathrm{a}}$ \\
\hline Ash (\%) & $5,87 \pm 0,03$ & $8,79 \pm 0,05^{\mathrm{a}}$ & $9,25 \pm 0,11^{\mathrm{ab}}$ & $9,53 \pm 0,13^{\mathrm{b}}$ & $9,46 \pm 0,37^{\mathrm{b}}$ & $9,42 \pm 0,32^{\mathrm{b}}$ & $9,41 \pm 0,15^{\mathrm{b}}$ \\
\hline Protein (\%) & $23,94 \pm 0,72$ & $36,55 \pm 0,38^{\mathrm{a}}$ & $36,95 \pm 0,08^{\mathrm{a}}$ & $39,31 \pm 0,12^{\mathrm{b}}$ & $37,10 \pm 0,15^{\mathrm{a}}$ & $39,50 \pm 0,06^{\mathrm{b}}$ & $40,10 \pm 0,32^{\mathrm{b}}$ \\
\hline Fat (\%) & $46,58 \pm 0,71$ & $37,69 \pm 0,74^{\mathrm{b}}$ & $36,28 \pm 0,16^{\mathrm{a}}$ & $36,63 \pm 0,09^{\mathrm{ab}}$ & $37,71 \pm 0,23^{\mathrm{b}}$ & $36,83 \pm 0,89^{\mathrm{ab}}$ & $36,99 \pm 0,08^{\mathrm{ab}}$ \\
\hline $\begin{array}{l}\text { Acidity (\%) } \\
\text { lactic acid) }\end{array}$ & $0,981 \pm 0,04$ & $1,674 \pm 0,05^{\mathrm{b}}$ & $1,592 \pm 0,01^{\mathrm{ab}}$ & $1,567 \pm 0,10^{\mathrm{ab}}$ & $1,611 \pm 0,06^{\mathrm{ab}}$ & $1,521 \pm 0,01^{\mathrm{a}}$ & $1,494 \pm 0,05^{\mathrm{a}}$ \\
\hline aw & 0,985 & $0,709 \pm 0,64^{\mathrm{ab}}$ & $0,716 \pm 0,43^{\mathrm{b}}$ & $0,700 \pm 0,68^{\mathrm{a}}$ & $0,701 \pm 0,00^{\mathrm{a}}$ & $0,705 \pm 0,29^{\mathrm{ab}}$ & $0,705 \pm 0,00^{\mathrm{ab}}$ \\
\hline
\end{tabular}

Table 1. Composition of Izmir Tulum cheese and dried cheese samples

${ }^{\mathrm{a}-\mathrm{b}}$ Means within a row with different superscripts differ for dried cheese samples $(P<0.05)$.

\subsection{Bulk and tapped densities, Carr Index value and water holding capacity}

Densities and flowability of the dried samples is important for the manufacturer and the end user for packaging, handling, storage, transportation, etc. The bulk densities of samples were found between 0,512 and $0,555 \mathrm{~g} / \mathrm{cm}^{3}$ (Table 2). The increase in drying temperature resulted in an increase in bulk densities of the samples. However, tapped density values of 
the samples did not significantly change with different drying conditions. The classification of the flowability based on Carr Index are very good $(<15)$, good (15-20), moderate $(20$ $35)$, bad (35-45), and very bad ( $>45)$. In this study, flowability of the samples was found to be moderate level. WHC of the samples varied from 33,0 to 35,6\%. The lowest WHC were obtained in samples dried at $1,8 \mathrm{~m} / \mathrm{s}$ air flow rate and $65^{\circ} \mathrm{C}$. This sample was found as harder in mouth by the panelists. The WHC of the samples dried at $1 \mathrm{~m} / \mathrm{s}$ were high when compared to the samples dried at $1,8 \mathrm{~m} / \mathrm{s}$ flow rate.

Table 2. Bulk and tapped densities, Carr Index and water holding capacity values of dried cheese samples

\begin{tabular}{|c|c|c|c|c|c|c|}
\hline Analysis & $1 \mathrm{~m} / \mathrm{s}-45^{\circ} \mathrm{C}$ & $1 \mathrm{~m} / \mathrm{s}-55^{\circ} \mathrm{C}$ & $1 \mathrm{~m} / \mathrm{s}-65^{\circ} \mathrm{C}$ & $1,8 \mathrm{~m} / \mathrm{s}-45^{\circ} \mathrm{C}$ & $1,8 \mathrm{~m} / \mathrm{s}-55^{\circ} \mathrm{C}$ & $1,8 \mathrm{~m} / \mathrm{s}-65^{\circ} \mathrm{C}$ \\
\hline $\mathrm{BD}\left(\mathrm{g} / \mathrm{cm}^{3}\right)$ & $0,512 \pm 0,00^{\mathrm{a}}$ & $0,533 \pm 0,00^{\mathrm{ab}}$ & $0,555 \pm 0,00^{\mathrm{b}}$ & $0,549 \pm 0,02^{\mathrm{b}}$ & $0,552 \pm 0,01^{b}$ & $0,552 \pm 0,00^{\mathrm{b}}$ \\
\hline$T D\left(g / \mathbf{c m}^{3}\right)$ & $0,713 \pm 0,05^{\mathrm{a}}$ & $0,728 \pm 0,07^{\mathrm{a}}$ & $0,731 \pm 0,04^{\mathrm{a}}$ & $0,741 \pm 0,05^{\mathrm{a}}$ & $0,726 \pm 0,06^{\mathrm{a}}$ & $0,729 \pm 0,06^{\mathrm{a}}$ \\
\hline CI & 28,1 & 26,7 & 24,0 & 25,9 & 23,3 & 24,3 \\
\hline WHC (\%) & $35,6 \pm 0,14^{\mathrm{c}}$ & $34,3 \pm 0,21^{\mathrm{bc}}$ & $33,4 \pm 0,35^{\mathrm{ab}}$ & $34,8 \pm 0,21^{\mathrm{c}}$ & $33,3 \pm 0,14^{\mathrm{ab}}$ & $33,0 \pm 0,07^{\mathrm{a}}$ \\
\hline
\end{tabular}

${ }^{a-b}$ Means within a row with different superscripts differ for dried cheese samples $(P<0.05)$. BD:bulk density, TD: tapped density, CI: Carr Index value, WHC: water holding capacity.

\subsection{Color evaluation}

Color of the dried foods is an important quality attribute for customer satisfaction and selection. The color values of dried samples were shown in Table 3. The lowest lightness and highest redness were found in samples dried at $65^{\circ} \mathrm{C}$ even at different air flow rates. Also, no significant changes were found in yellowness of the samples with the changes in air flow rates or temperature. $\Delta \mathrm{E}$ values of the samples calculated with reference sampleIzmir Tulum cheese. When $\Delta \mathrm{E}$ value is greater than 3 , it can be distinguished by eyes easily [13]. All samples have $\Delta \mathrm{E}$ value higher than 3. Therefore, their differences were distinguished by eyes. However, increase in air flow rate at same temperature resulted in a decrease in $\Delta \mathrm{E}$ value.

Table 3. Color values of dried cheese samples

\begin{tabular}{|c|c|c|c|c|c|}
\hline & $\mathbf{L}$ & $\mathbf{A}$ & B & $\Delta \mathbf{E}$ & Chroma \\
\hline $\begin{array}{c}\text { Drying } \\
\text { Conditions }\end{array}$ & $85,29 \pm 0,41$ & $2,18 \pm 0,00$ & $25,19 \pm 0,06$ & - & - \\
\hline $1 \mathrm{~m} / \mathrm{s}-45^{\circ} \mathrm{C}$ & $83,58 \pm 0,91^{\mathrm{ab}}$ & $3,36 \pm 0,06^{\mathrm{a}}$ & $36,41 \pm 0,13^{\mathrm{b}}$ & $11,4 \pm 0,27^{\mathrm{bc}}$ & $36,57 \pm 0,14^{b}$ \\
\hline $1 \mathrm{~m} / \mathrm{s}-55^{\circ} \mathrm{C}$ & $84,38 \pm 0,61^{\mathrm{b}}$ & $3,23 \pm 0,04^{\mathrm{a}}$ & $35,38 \pm 0,35^{\mathrm{ab}}$ & $10,3 \pm 0,28^{\mathrm{ab}}$ & $35,53 \pm 0,34^{\mathrm{ab}}$ \\
\hline $1 \mathrm{~m} / \mathrm{s}-65^{\circ} \mathrm{C}$ & $82,18 \pm 0,97^{\mathrm{a}}$ & $5,01 \pm 0,11^{\mathrm{c}}$ & $36,13 \pm 0,74^{\mathrm{b}}$ & $11,7 \pm 0,97^{\mathrm{c}}$ & $36,48 \pm 0,74^{b}$ \\
\hline $1,8 \mathrm{~m} / \mathrm{s}-45^{\circ} \mathrm{C}$ & $83,25 \pm 0,00^{\mathrm{ab}}$ & $3,37 \pm 0,23^{\mathrm{a}}$ & $35,76 \pm 0,23^{\mathrm{ab}}$ & $10,8 \pm 0,24^{\mathrm{ab}}$ & $35,92 \pm 0,24^{\mathrm{ab}}$ \\
\hline $1,8 \mathrm{~m} / \mathrm{s}-55^{\circ} \mathrm{C}$ & $84,03 \pm 0,41^{\mathrm{b}}$ & $3,30 \pm 0,12^{\mathrm{a}}$ & $35,03 \pm 0,57^{\mathrm{a}}$ & $10,00 \pm 0,60^{\mathrm{a}}$ & $35,19 \pm 0,56^{\mathrm{a}}$ \\
\hline $1,8 \mathrm{~m} / \mathrm{s}-65^{\circ} \mathrm{C}$ & $82,88 \pm 0,23^{\mathrm{ab}}$ & $4,17 \pm 0,37^{b}$ & $35,58 \pm 0,01^{\mathrm{ab}}$ & $10,8 \pm 0,03^{\mathrm{ab}}$ & $35,83 \pm 0,06^{\mathrm{ab}}$ \\
\hline
\end{tabular}

${ }^{\mathrm{a}-\mathrm{c}}$ Means within a row with different superscripts differ for dried cheese samples $(P<0.05)$. 


\subsection{Sensory evaluation}

The sensory evaluation results were shown in Table 4 . The samples that were dried at $1 \mathrm{~m} / \mathrm{s}$ $-55^{\circ} \mathrm{C}$ had the highest score in terms of taste and overall acceptability, whereas lowest scores were found in samples dried at $65^{\circ} \mathrm{C}$. However, the samples that exposed to drying at $1.8 \mathrm{~m} / \mathrm{s}-65^{\circ} \mathrm{C}$ has the highest score in terms of color and appearance.

Table 4. Sensory evaluation results for dried cheese samples

\begin{tabular}{|c|c|c|c|c|c|}
\hline $\begin{array}{c}\text { Drying } \\
\text { Conditions }\end{array}$ & Color & Appearance & Texture & Flavor & $\begin{array}{c}\text { Overall } \\
\text { acceptability }\end{array}$ \\
\hline $1 \mathrm{~m} / \mathrm{s}-45^{\circ} \mathrm{C}$ & $3,37 \pm 0,25^{\mathrm{a}}$ & $3,42 \pm 0,33^{\mathrm{ab}}$ & $3,66 \pm 0,13^{\mathrm{c}}$ & $3,51 \pm 0,05^{\mathrm{ab}}$ & $3,76 \pm 0,13^{\mathrm{ab}}$ \\
\hline $1 \mathrm{~m} / \mathrm{s}-55^{\circ} \mathrm{C}$ & $3,51 \pm 0,26^{\mathrm{ab}}$ & $3,44 \pm 0,08^{\mathrm{ab}}$ & $3,48 \pm 0,12^{\mathrm{bc}}$ & $3,92 \pm 0,11^{\mathrm{b}}$ & $3,89 \pm 0,35^{\mathrm{b}}$ \\
\hline $1 \mathrm{~m} / \mathrm{s}-65^{\circ} \mathrm{C}$ & $3,49 \pm 0,43^{\mathrm{ab}}$ & $3,20 \pm 0,49^{\mathrm{a}}$ & $2,58 \pm 0,12^{\mathrm{a}}$ & $3,21 \pm 0,28^{\mathrm{ab}}$ & $3,12 \pm 0,00^{\mathrm{a}}$ \\
\hline $1,8 \mathrm{~m} / \mathrm{s}-45^{\circ} \mathrm{C}$ & $3,56 \pm 0,26^{\mathrm{ab}}$ & $3,42 \pm 0,56^{\mathrm{ab}}$ & $3,00 \pm 0,21^{\mathrm{ab}}$ & $3,20 \pm 0,48^{a b}$ & $3,45 \pm 0,64^{\mathrm{ab}}$ \\
\hline $1,8 \mathrm{~m} / \mathrm{s}-55^{\circ} \mathrm{C}$ & $3,52 \pm 0,61^{\mathrm{ab}}$ & $3,42 \pm 0,53^{\mathrm{ab}}$ & $3,08 \pm 0,45^{\mathrm{ab}}$ & $3,25 \pm 0,35^{\mathrm{ab}}$ & $3,32 \pm 0,39^{\mathrm{ab}}$ \\
\hline $1,8 \mathrm{~m} / \mathrm{s}-65^{\circ} \mathrm{C}$ & $3,68 \pm 0,37^{b}$ & $3,59 \pm 0,15^{\mathrm{b}}$ & $2,98 \pm 0,31^{\mathrm{a}}$ & $3,03 \pm 0,45^{\mathrm{a}}$ & $3,17 \pm 0,25^{\mathrm{ab}}$ \\
\hline
\end{tabular}

${ }^{\mathrm{a}-\mathrm{c}}$ Means within a row with different superscripts differ for dried cheese samples $(P<0.05)$.

\section{Conclusions}

Higher water activity of foods tends to support the growth of microorganisms, especially molds which causes quality depletion and economical losses. Molds require a water activity level at least 0.80 . In this study, the water activity of the dried Izmir Tulum cheese samples did not change with different drying conditions, and samples had water activity values that were below 0.72 . Although the densities and water holding capacity of samples changed by the drying parameters, these differences were not very important from the practical point of view. On the other hand, increasing air flow rate and temperature resulted in harder surface of samples, which was not preferred by panelists. The highest flavor and overall impression scores were found in samples dried at $1 \mathrm{~m} / \mathrm{s}$ and $55^{\circ} \mathrm{C}$. In conclusion, a dried cheese using a tray drier has several advantages such as easy to transport, store and packaging. However, there is a need a further study to evaluate the storage stability of the product.

\section{Acknowledgements}

The authors are grateful for the financial support provided for the project code: 2209-A by the Scientific and Technological Research Council of Turkey (TUBITAK, Ankara, Turkey).

\section{References}

[1] Fox, P.F.; Cogan, T.M.; Guinee, T.P.; McSweeney, P.L.H. Fundamentals of Cheese Science; Aspen Publications: Gaithersburg, 2000.

[2] Guinee, T.P.; Kilcawley, K.N. Cheese: Cheese as an ingredient. In Cheese Chemistry, Physics and Microbiology; Fox, P.F., McSweeney, P.L.H., Cogan, T.M., Guinee, T.P., 
Eds.; Elsevier/Academic Press: London, 2004; 395-428.

[3] Guinee, T.P. Cheese as a food ingredient. In Encyclopedia of Dairy Sciences; Fuquay, J.W., Fox, P.F., McSweeney, P.L.H., Eds.; Elsevier/Academic Press: London, 2011; $822-833$.

[4] International Dairy Federation. Determination of the total solid content (cheese and processed cheese). IDF Standard 4A. International Dairy Federation (IDF): Brussels, 1982.

[5] AOAC. Official methods of analysis of AOAC International. 18th ed. AOAC International: Gaithersburg, 2007.

[6] International Dairy Federation. Cheese, determination of fat content - Van Gulik butyrometers method. IDF Standard 5B, International Dairy Federation (IDF): Brussels, 1986.

[7] International Dairy Federation. Milk-Determination of fat content-Gerber butyrometers. IDF Standard 105. International Dairy Federation (IDF): Brussels, 1981.

[8] Jinapong, N.; Suphantharika, M.; Jamnong, P. Production of instant soymilk powders by ultrafiltration, spray drying and fluidized bed agglomeration. Journal of Food Engineering 2008, 84, 194-205.

[9] Carr, R.L. Evaluating flow properties of solids. Chemical Engineering 1965, 72, 163168.

[10] Heywood, A.A.; Myers, D.J.; Bailey, T.B.; Johnson, L.A. Functional properties of low-fat soy flour produced by an extrusion-expelling system. Journal of the American Oil Chemists' Society 2002, 79(12), 1249-1253.

[11] Traynham, T.L.; Myers, D.J.; Carriquiry, A.L.; Johnson, L.A. Evaluation of waterholding capacity for wheat-soy flour blends. Journal of the American Oil Chemists' Society 2007, 84(2), 151-155.

[12] Askari, G.R.; Emam-Djomeh, Z.; Mousavi, S.M. Investigation of microwave treatment on the optical properties of apple slices during drying. Drying Technology 2008, 26, 1362-1368.

[13] Francis, F.J.; Clydesdale, F.M. Food colorimetry: Theory and applications. Molecular Nutrition and Food Research 1977, 21(1), 90-91. 